\title{
Assessment of the Microbiological Quality of Drinking Water in Light of Water Quality in the Pelengana Commune of Segou Region
}

\author{
Hawa Diakite ${ }^{1}$, Yujuan Gao ${ }^{1 *}$, Amadou Toure ${ }^{2}$ \\ ${ }^{1}$ College of Economics and Management, Northeast Forestry University, Harbin, China \\ ${ }^{2}$ School of Forestry, Northeast Forestry University, Harbin, China \\ Email: hawadiakite60@yahoo.fr, ^441896083@qq.com, touamare03@yahoo.fr
}

How to cite this paper: Diakite, H., Gao, Y. and Toure, A. (2019) Assessment of the Microbiological Quality of Drinking Water in Light of Water Quality in the Pelengana Commune of Segou Region. Computational Water, Energy, and Environmental Engineering, 8, 79-89.

https://doi.org/10.4236/cweee.2019.83005

Received: May 22, 2019

Accepted: July 2, 2019

Published: July 5, 2019

Copyright $\odot 2019$ by author(s) and Scientific Research Publishing Inc. This work is licensed under the Creative Commons Attribution International License (CC BY 4.0).

http://creativecommons.org/licenses/by/4.0/

(C) (i) Open Access

\begin{abstract}
This study focused to determine the bacteriological quality of different commonly used water sources, including boreholes, hand pumps, surface water, household containers, dug well and cement reservoirs in Pelengana commune, in Mali with special reference to the internally displaced people camps. Four hundred and eight water samples were collected from different sites and sources, from July 2016 to June 2017. Water samples were examined for total coliform, fecal coliform and fecal enterococci counts using the most probable number method. Also, samples were investigated for the presence of enteric bacteria isolated, namely Escherichia coli, Enterococcus fecalis, Bacillus, Citrobacter and Enterobacter. Results revealed that the three indicators bacteria (Total Coliform (48.7\%), Fecal Coliform (100\%), and Fecal enterococci (37.01\%)) were found above permissible limit for drinking water. The highest number of the indicators bacteria found was $1800 \mathrm{TC} / 100 \mathrm{ml}$ water. Enteric bacteria isolated were Escherichia coli (25.7\%), Enterococcus fecalis (21.91\%), Bacillus (16.72\%), Enterobacter (4.56\%) and Citrobacter (3.91\%). The most contaminated water source was surface water $(15.28 \%)$ followed by household containers (13.65\%), boreholes (8.75\%), cement reservoirs $(7.47 \%)$, hand pumps (5.31\%) and dug wells (2.7\%). These findings illustrate that contamination varied with seasons, and the highest level was observed in rainy season (30.02\%) compared to the dry season (23.14\%). All sources of water in the study sites were contaminated. It is suggested that the outright prevention of surface water consumption should be employed and monitoring of the quality of water resources is needed.
\end{abstract}

\section{Keywords}

Water Microbiology, Total Coliform Count, Fecal Coliform Count, Fecal 


\section{Introduction}

The microbiological quality of drinking water has brought about great preoccupation to mankind because of implied public health repercussions. Bad quality of drinking water, poor sanitation and hygiene have been pointed out among the 20 top risk factors for health burden in developing countries [1]. Detection of bacterial indicators in drinking water involves the presence of pathogenic organisms that are the source of waterborne diseases which could be deadly [2]. The supply of drinking water of sufficient quality and quantity remains a crucial public health need in most African countries, including Mali, where diarrhoeal diseases continue to cause particularly high mortality [3]. However, according to the World Health Organization (WHO), about 1.1 billion human beings lack good quality water and 2.4 billion do not have access to adequate sanitation. More than 2 million people, especially children below five years in developing countries with insufficient hygiene and sanitation, die each year by diarrheal diseases [4]. The water for human consumption must not contain organisms and chemical substances in concentrations sufficiently high to affect health [5].

Nevertheless, most Malian water supply systems are still intermittent systems with irregular pressure and questionable water quality [2]. Water is not continuously available, and this makes water storage at the household level necessary. This storage is considered a challenge and an opportunity at the same time: the possible recontamination of drinking water between source and point-of-use is well-recognized, as is the ability of households to reduce bacterial contamination by home treatment [5]. There are two concepts that have shown the potential to improve drinking water quality and lower the burden of diarrheal disease. "Household water treatment and storage" (HWTS) interventions help to ensure the microbiological safety of water. They include point-of-use water treatment technologies (e.g., boiling, solar disinfection, chlorination, filtration, or other chemical treatment) as well as improved transport, storage, and handling practices for potable water (e.g., storage in clean containers, preferably with narrow dispensers or long-handled ladles to extract the water). "Water, sanitation, and hygiene" (WASH) practices target the issues of safe water supply, improved sanitation, and hygiene behaviors in an integrated way. WASH practices comprise good personal hygiene practices, such as regular hand-washing with soap and good food hygiene practices, the availability of sanitation facilities and the safe disposal of feces, as well as access to safe water supply points [5]. Both HWTS interventions and WASH practices have been shown to be useful in the reduction of diarrhea occurrence [4], but their protective effect varied in different studies, and their effectiveness seemed to have deteriorated over time as people stopped using them [2]. 
Many studies have focused on water supply and public health in sub-Saharan Africa, but comparatively few data are available from Mali in general and no study was conducted regarding microbiological quality of water consumed by people living in rural area of Segou region in particular [6].

In recent years, a rebellion associated with terrorism ruptured in northern part of Mali, bringing thousands of people to move into the peripheral areas of Pelengana commune in Segou region. These communities live in rural areas characterized by overcrowding, poor dwelling and inadequate water and sanitation. In such situations, waterborne diseases that are generally associated with poor hygiene and sanitation can assign a majority of the population [7]. Therefore access to safe drinking water and suitable sanitation is a priority. However, data from different health centers of Pelengana commune has identified waterborne diseases as the main diseases that affect this community living in different camps of internally displaced people. Hence the present study was designed to evaluate the bacteriological quality of water in Pelengana commune, Segou, Mali with special reference to the internally displaced people camps.

\section{Material and Methods}

\subsection{Study Area}

The study was conducted in the rural commune of Pelengana in Segou region. The region is located in the center of Mali between $12^{\circ} 30^{\prime}$ and $15^{\circ} 30^{\prime} \mathrm{N}$ latitude and $4^{\circ}$ and $7^{\circ} \mathrm{W}$ longitude, with a total area of $62,504 \mathrm{~km}^{2}$ and a population of 2 338,349 based on the 2009 census [8]. Currently, the commune of Pelengana has more than 10,500 displaced people. They are settled in villages inside the commune, and these villages are reported in (Figure 1). Segou region has a Sudano-Sahelian climate with two seasons, dry season that lasts eight months (October-May), and rainy season that lasts four months (June-September). Rainfall of

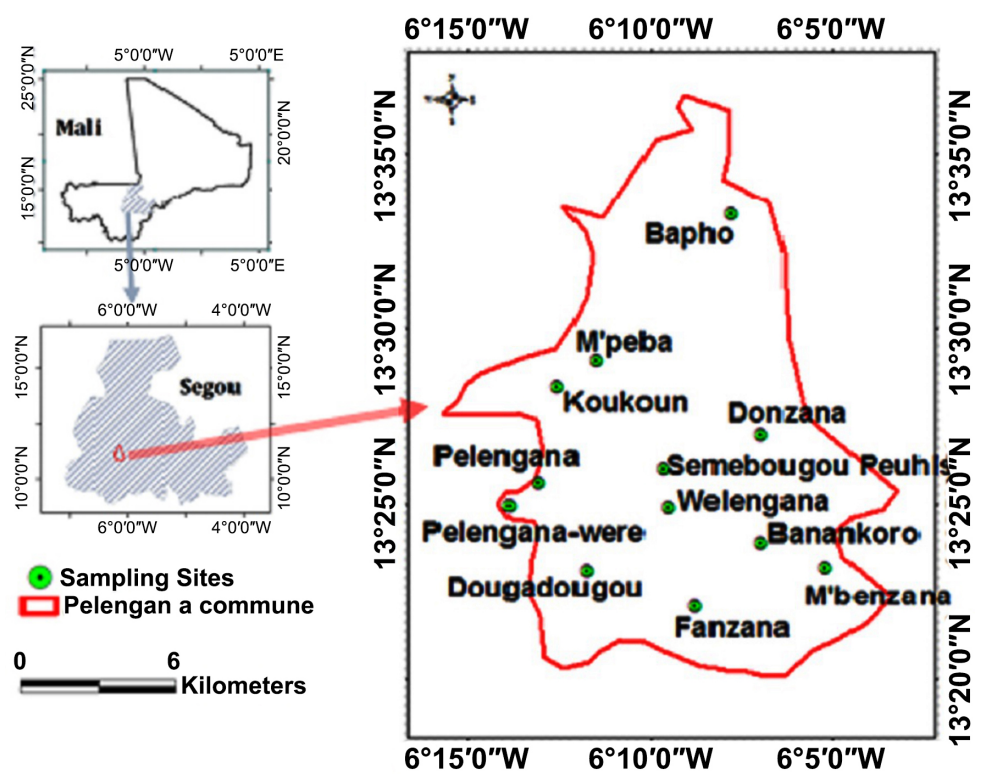

Figure 1. Map of sampling sites in the rural commune of Pelengana. 
the region ranges between 200 to $800 \mathrm{~mm}$ per year and the average temperature is $28^{\circ} \mathrm{C}$ [9]. Agriculture, livestock and fishing are the main activities of the region [10].

\subsection{Water Sample Collection}

The sampling was carried out throughout 12 months during the two seasons, from July 2016 to June 2017 in each site. A total of four hundred and eight water samples were collected from twelve different sites in study area. Samples were collected from different supply sources including boreholes equipped with submersible pumps, hand pumps, surface water, household containers (canaries), dug well and cement reservoirs. Water samples were collected in $1 \mathrm{~L}$ polyethylene flacons. These flacons were earlier washed with detergent, rinsed with tap water as well as with distilled water, and then rinsed three times with the sampled water from the sources. The water samples were carefully labeled and stored in a cooler at a temperature between $0^{\circ} \mathrm{C}$ and $4^{\circ} \mathrm{C}$. Then they were delivered to the microbiology laboratory within six hours of their collection for further processing.

\subsection{Microbiology}

Fecal streptococci, Total and fecal coliform, were enumerated by multiple tube fermentation tests [11] [12]. Coliform count was obtained using the three tube assay of the Most Probable Number (MPN) technique. Presumptive coliform test was carried out using MacConkey broth (oxoid). The first set of the three tubes had sterile $10 \mathrm{ml}$ double strength broth lactose broth (DSLB) and the second and third sets had $10 \mathrm{ml}$ single strength lactose broth (SSLB). All the tubes contained Durham tube before sterilization. The three sets of the tubes received 10, 1 and $0.1 \mathrm{ml}$ of water samples using sterile pipettes. The tubes were incubated at $37^{\circ} \mathrm{C}$ for $24-48$ hours for estimation of total coliforms, at $44.5^{\circ} \mathrm{C}$ for fecal coliforms for $24-48$ hours, and at $37^{\circ} \mathrm{C}$ for 24 hours for fecal streptococci and examined for acid and gas production. Acid production was determined by color change of the broth from reddish purple to yellow and gas production was checked for by entrapment of gas in the Durham tube. The MPN was then determined from the MPN table for the three sets of tube [11] [12].

Confirmed test: Confirmed test was carried out by transferring a loopful of culture from a positive tube from presumptive test into a tube of Brilliant Green Lactose Bile (BGLB) broth (oxoid) with Durham tubes. The tubes were incubated at $37^{\circ} \mathrm{C}$ for $24-48$ hours for total coliform and $44.5^{\circ} \mathrm{C}$ for fecal coliforms and observed for gas production [11].

Completed test: Completed test was carried out by streaking a loopful of broth from a positive tube onto Eosine Methylene Blue (EMB) agar plate for pure colonies. The plates were incubated at $37^{\circ} \mathrm{C}$ for $24-48$ hours. Colonies developing on EMB agar were further identified as fecal coliforms (Escherichia coli). Colonies with green metallic sheen were confirmed to be fecal coliform bacteria with rods shape [11]. Statistical Package for Social Sciences (SPSS) version 21.0 was used to analyze the obtained data. Prevalence and percentage was cal- 
culated for microbiological contamination of water samples.

\section{Results}

\subsection{Indicator of Bacterial Count per $100 \mathrm{ml}$ of All Water Samples}

In the study area, 408 water samples were tested, out of the total, $48.7 \%$ denoted a higher than standard (10 coliform $/ 100 \mathrm{ml}$ ) count of low risk for total coliforms. On the other hand, $100 \%$ of total coliforms have expressed fecal coliforms count above the norm ( 0 fecal coliforms $/ 100 \mathrm{ml}$ ) for drinking water. Whereas $37.01 \%$ of all samples certified that the Enterococcus group exceeded the standard (0 enterococci $/ 100 \mathrm{ml}$ ) for drinking water (Table 1 ).

\subsection{Prevalence of Total Coliform, Fecal Coliform and Fecal Enterococci}

The results showed that the highest prevalence of total coliform (8.27\%), fecal coliform $(8.02 \%)$, and fecal enterococci $(6.30 \%)$, was seen in surface water, seconded by household containers in rainy season. Whereas the lowest $(0.95 \%)$ prevalence of all bacterial groups was observed in dug wells during the dry season. Total coliform and fecal coliform showed $4.03 \%$ prevalence in cement reservoirs in rainy season. An equal diminution in prevalence to $3.44 \%$ of total coliform and fecal coliform was seen in dry season. Boreholes indicated slight differences between the prevalence of total coliform (5.33\%) and fecal coliform (5.31\%) in rainy season whereas they decline in dry season. Fecal enterococci revealed an increase of prevalence in boreholes (3.30\%) in rainy season followed by a decrease to $2.15 \%$ in dry season. The three groups of bacteria revealed the same description of an increase of prevalence in hand pumps in rainy season followed by a decrease in dry season (Table 2).

Table 1. Indicators bacterial count per $100 \mathrm{ml}$ of all samples.

\begin{tabular}{ccccccccc}
\hline \multicolumn{2}{c}{ Total coliform count } & \multicolumn{3}{c}{ Fecal coliform count } & \multicolumn{3}{c}{ Enterococci group count } \\
\hline MPN & Freq & $\%$ & MPN & Freq & $\%$ & MPN & Freq & $\%$ \\
\hline$\leq 10$. TC $/ 100 \mathrm{ml}$ & 209 & 51.3 & $\leq 0 . \mathrm{FC} / 100 \mathrm{ml}$ & 0 & 0.0 & $\leq 0 . \mathrm{En} / 100 \mathrm{ml}$ & 257 & 62.99 \\
$\geq 10 . \mathrm{TC} / 100 \mathrm{ml}$ & 199 & 48.7 & $\geq 0 . \mathrm{FC} / 100 \mathrm{ml}$ & 199 & 100 & $\geq 0 . \mathrm{En} / 100 \mathrm{ml}$ & 151 & 37.01 \\
Total & 408 & 100 & & 199 & 100 & & 408 & 100 \\
\hline
\end{tabular}

MPN most probable number of bacteria, TC total coliform, FC fecal coliform, En Enterococcus group.

Table 2. Prevalence of total coliform, fecal coliform and fecal enterococci in different seasons and sources.

\begin{tabular}{|c|c|c|c|c|c|c|c|c|c|c|c|c|}
\hline Season & & & Dry & & & & & & Rainy & & & \\
\hline $\begin{array}{c}\text { Sources } \\
\text { Microorganism }\end{array}$ & Boreholes & $\begin{array}{l}\text { Surface } \\
\text { water }\end{array}$ & $\begin{array}{l}\text { Household } \\
\text { containers }\end{array}$ & $\begin{array}{l}\text { Dug } \\
\text { well }\end{array}$ & $\begin{array}{l}\text { Hand } \\
\text { pumps }\end{array}$ & $\begin{array}{l}\text { Cement } \\
\text { reservoirs }\end{array}$ & Boreholes & $\begin{array}{l}\text { Surface } \\
\text { water }\end{array}$ & $\begin{array}{l}\text { Household } \\
\text { containers }\end{array}$ & $\begin{array}{l}\text { Dug } \\
\text { well }\end{array}$ & $\begin{array}{l}\text { Hand } \\
\text { pumps }\end{array}$ & $\begin{array}{l}\text { Cement } \\
\text { reservoirs }\end{array}$ \\
\hline Total coliform \% & 3.42 & 7.01 & 6.46 & 0.95 & 1.86 & 3.44 & 5.33 & 8.27 & 7.19 & 1.75 & 3.45 & 4.03 \\
\hline Fecal coliform \% & 3.01 & 7.02 & 6.46 & 0.95 & 1.84 & 3.44 & 5.31 & 8.02 & 7.10 & 1.75 & 3.12 & 4.03 \\
\hline Fecal enterococci \% & 2.15 & 4.45 & 4.25 & 0.95 & 1.02 & 2.17 & 3.30 & $6.3 \%$ & $4.32 \%$ & 1.83 & $2.45 \%$ & $3.19 \%$ \\
\hline
\end{tabular}




\subsection{Bacteria Isolated}

Five enteric bacteria isolated in total were identified. These genera include: Escherichia coli (25.7\%), Enterococcus fecalis (21.91\%), Bacillus (16.72\%), Citrobacter (3.91\%) and Enterobacter (4.56\%). In all seasons, E. coli had the highest percentage frequency isolated bacteria from different sources $(6.32 \%)$ followed by Enterococcus fecalis (4.82\%) with the highest contamination in surface water in rainy season. Also Bacillus with the highest contamination (3.92\%) in boreholes and household containers (canaries) in rainy season. Not frequently isolated bacteria were Citrobacter and Enterobacter that revealed constant frequencies of $(0.59 \%$ and $0.93 \%)$ in household containers in rainy season and dry season, respectively. Surface water and household containers revealed continuous level of contamination by all different bacteria during the two seasons. Cement reservoirs, hand pumps, boreholes and dug wells were followed (Table 3).

\section{Discussions}

Water is an essential and irreplaceable element to ensure the continuity of life and health. Therefore, in urgency situation the security of the water must be guaranteed right through for using at home, since interruption in the provision may be catastrophic. Thus, this study focused to determine the microbiological quality of water at different sources and points of consumption in Pelengana commune using multiple tube fermentation Technique to detect and count bacteria that are designated as signs of fecal contamination and attendance of pathogens [13] [14]. The results indicated that the sources of water analyzed were

Table 3. Bacteria isolated from sources in different season.

\begin{tabular}{|c|c|c|c|c|c|c|}
\hline \multirow[b]{2}{*}{ Seasons } & \multirow[b]{2}{*}{ Sources } & \multicolumn{5}{|c|}{ Isolate } \\
\hline & & E. coli & $\begin{array}{c}\text { Enterococcus } \\
\text { fecalis }\end{array}$ & Bacillus & Citrobacter & Enterobacter \\
\hline \multirow{6}{*}{ Rainy } & Surface water & $6.32 \%$ & $4.82 \%$ & $3.22 \%$ & $0.93 \%$ & $0.93 \%$ \\
\hline & Boreholes & - & $2.45 \%$ & $3.92 \%$ & - & - \\
\hline & Household containers & $3.01 \%$ & $2.85 \%$ & $3.92 \%$ & $0.59 \%$ & $0.93 \%$ \\
\hline & Dug well & $0.47 \%$ & $0.98 \%$ & - & - & - \\
\hline & Hand pumps & $2.14 \%$ & $1.33 \%$ & $1.15 \%$ & - & - \\
\hline & Cement reservoirs & $2.15 \%$ & $1.85 \%$ & $0.84 \%$ & $0.93 \%$ & $0.59 \%$ \\
\hline \multirow{6}{*}{ Dry } & Surface water & $4.08 \%$ & $3.13 \%$ & $2.25 \%$ & $0.93 \%$ & $0.59 \%$ \\
\hline & Boreholes & $1.23 \%$ & $0.40 \%$ & - & - & - \\
\hline & Household containers & $2.87 \%$ & $1.33 \%$ & $1.00 \%$ & $0.59 \%$ & $0.93 \%$ \\
\hline & Dug well & - & $0.81 \%$ & - & - & - \\
\hline & Hand pumps & $1.56 \%$ & $0.54 \%$ & - & - & - \\
\hline & Cement reservoirs & $1.87 \%$ & $1.42 \%$ & $0.42 \%$ & - & - \\
\hline
\end{tabular}


contaminated with most of indicator bacteria with significant variation in counts. Among the water samples examined, $48.7 \%$ express a total coliform, $100 \%$ of which contain fecal coliforms exceeding the admissible level of WHO standard for these bacteria. This denotes excessive water contamination and the probability of dangerous presence of very pathogenic bacteria such as $E$. coli and Bacillus in water and therefore a high prevalence of diarrheal diseases in the community. On the other hand, 37.01\% of samples harbour Enterococcus group such as Enterococcus fecalis that bring about urinary tract and wound infections. The number of indicator bacteria $(0-1800 \mathrm{TC} / 100 \mathrm{ml})$ in this work is rather higher compared to other researchers. Total coliform count of (16102) cells per100ml in drinking water in South Darfur mentioned by Amira et al. (2010). Observations similar to those from Lomé well water were reported in Meknes, Morocco, for fecal coliform bacteria [15]. This variation in count could be attributable not only to the environment and conduct of the population such as the lack of a system for the collection, defecation and infiltration of organic matter in the soil, but also the difference in samples number in each study.

Total coliform was identified with significant variation in different seasons (dry, rainy) and sources (water sources, water storage reservoirs). In a rainy season, surface water recorded the highest prevalence of total coliform, seconded by household containers. This fact may be attributed on one hand, to the runoff flows and human activities affecting surface water sources. On the other hand, due to the wind blowing during the rainy season, which transmits dirt and pathogens to unprotected storage containers (i.e. containers without lids), storing water in areas that are not sheltered by children, insects and animals. A study in Zimbabwe showed that simply covering the water reservoir reduced total coliforms by $50 \%$ in water stored in households [16]. While lowest of total coliform were found in cement reservoirs, hand pumps and dug wells water samples compared to the high prevalence in surface waters and household containers. However, contamination of other water sources (cement reservoirs, hand pumps and dug wells) is explained by poor protection of water sources and non-compliance with protection perimeters. Similarly, the absence of appropriate sanitation system and surrounding pollution such as agricultural land, cattle breeding, the existence of septic tanks and latrines are largely involved in this pollution [17]. Evidently, contamination of groundwater by coliform has negative consequences on public health. Thus, the authors stated that the bacteriological pollution of the deep water table is more worrying because it could mean a general insalubrity of the groundwater of the city, due to vertical percolation of the pollutants contained in the surface levels. Groundwater pollutants have the capacity to move through soil particles to the groundwater. Soil purification process can break, thereby rendering groundwater very sensitive to pollution. Hence, boreholes, hand pumps and wells must be located at recommended safe distances in order to prevent potential contaminants [18].

In dry season, the decrease prevalence of total coliform in household containers is occasioned by the heavy consumption of water due to heat; newly chlori- 
nated water will be added to the storage container day-to-day, residual chlorine in quotidian added fresh water will affect survival of existing pathogenic organisms. In a rainy season, the increase prevalence of total coliform in surface water, household containers, borehole, cement reservoirs, hand pumps and dug wells noticed is likely due to leaching action of the rainfall [14]-[19].

Fecal coliform were noticed exceeding the admissible limits set by World Health Organization (WHO) for potable water in both rainy and dry seasons and different sources during this study. Indeed, according to recommendations of WHO, fecal coliforms should not exist in $100 \mathrm{ml}$ water sample. It arises exclusively from the intestines of warm-blooded animals, including humans, and its presence is the most accurate indicator of fecal contamination [20]. Although the presence of Fecal coliform in water indicates fecal contamination, it does not identify the precise source of fecal matters. There are several sources: manure, grazing, septic tanks, latrine and other sources such as wildlife. According to our surveys of the water sources sites studied, we noticed the existence of manure, septic tanks and pit latrines and waste of all kinds on the land around the water sources. In addition, several animals were observed near the sampling sites (dogs, goats, donkeys, oxen, chickens), which represents a fairly significant contamination potential. All the boreholes, hand pumps and dug wells were approximately within a $50 \mathrm{~m}$ or less radius from pit latrines, refuse tips and other social amenities. The presence of fecal coliforms may be an indication of the presence of enteropathogenic microorganisms [21], such as Salmonellae and Norwalk virus [22]. Indeed, according to the WHO guidelines, any water intended for human consumption should not contain E. coli or fecal coliform bacteria [23]. Water samples analyzed in the laboratory throughout this study showed that water sources are highly contaminated by fecal matters and particularly surface water and household containers. These are propagated through the manual dumping of human and animal waste by humans and animals or through flooding. Conditions for the collection, transport, storage, and handling of drinking water can contribute to contamination. It is recognized that where elementary sanitation is deficient, there is more probability of indicator bacteria from feces being introduced into stored water [14]-[24].

In this study, 151 (37.01\%) of the water samples had Enterococcus group count above the zero per $100 \mathrm{ml}$. High prevalence of Enterococcus group was seen in rainy season, the low one in dry season with the highest prevalence in surface water. Enterococcus group delivers additional data on bacteriological quality of water and increases fecal contamination of water [25]. Results suggest surface source waters structures were often poorly protected, which greatly accentuated the degree of contamination of these waters. However, surface waters can receive direct contamination by domestic sewage from humans and animals or agricultural land runoffs which contain fecal matter or chemicals [26]. It is important to note that in Pelengana commune, particularly in camps for internally displaced persons, surface waters are the source of water for both humans and livestock's, there are multiple contributes factors, namely poor utilization, 
lack of cleaning and different handling, which is not easy to avoid. Certain researchers indicated that the percentage of sample testing positive for indicator bacteria may lessen after collection of heavily contaminated sources due to bacterial death due to oxygen and restricted nutrients in water [27]. In rainy season, surface water recorded in this study the highest prevalence of E. coli and Enterococcus fecalis compared to low prevalence in other sources. Furthermore, other coliform namely Bacillus, Citrobacter and Enterobacter species isolated in drinking water enhance the probability of the existence of pathogenic bacteria. E. coli $(25.7 \%)$, the first predominant isolate is a significant public health concern as it is one of the main causes of infectious diseases such as diarrhea, urinary tract infection, haemorrhagic colitis and haemolytic uraemia syndrome [28]. Furthermore, Bacillus (16.72\%) is associated with a variety of infectious diseases such as gastrointestinal tract, urinary tract and respiratory tract infection [29]. In addition, Enterobacter (4.56\%) and Citrobacter (3.91\%) species were also identified as the main causes of cystitis, enteritis, pneumonia, diarrhea and food poisoning [14]-[30].

\section{Conclusion}

This study investigated the bacteriological quality of different sources of water in selected sites in Pelengana commune, Segou, Mali with special reference to displaced people camps. It was discovered that all the sites provided water which were unfit for consumption. The percentages of the three-indicator bacterial count identified exceed the standard limits for safe drinking water in all samples. The degree of contamination was dug wells $<$ hand pumps $<$ cement reservoirs $<$ boreholes $<$ household containers $<$ surface water. These findings illustrate that contamination varied with seasons, and the highest level was observed in rainy season. It is suggested that the outright prevention of surface water consumption should be employed and monitoring of the quality of water resources is needed. Therefore, population using these water sources should be educated about the probable risks when water from these different sources is used for human consumption. Education should also include possible means of treatment of water such as boiling and use of chlorination tablets to avoid potential adverse effects on the health. Moreover, population involvement through protection of drinking water sources from contamination could contribute to improving the water situation throughout the region, thus ensuring a healthy environment, for instance, rules governing activities within the area, particularly pit latrine sitting, best management practices for farming, general hygiene and adequate storage practices at household level.

\section{Acknowledgements}

The authors acknowledge the central Water Quality Laboratory (SOMAGEP) personnel for their support in laboratory analyses. Thanks to the anonymous reviewers for comments on the previous version which helped to improve the 
manuscript. Authors would also like to thank the villagers for wholehearted participation in this study.

\section{Conflicts of Interest}

The authors declare no conflicts of interest regarding the publication of this paper.

\section{References}

[1] WHO (2003) Emerging Issues in Water and Infectious Disease. WHO, Geneva.

[2] Wolf, J., Prüss-Ustün, A., Cumming, O., Bartram, J., Bonjour, S., Cairncross, S., Clasen, T., Colford, J.M., Curtis, V., de France, J., et al. (2014) Systematic Review: Assessing the Impact of Drinking Water and Sanitation on Diarrhoeal Disease in Low- and Middle-Income Settings: Systematic Review and Meta-Regression. Tropical Medicine \& International Health, 19, 928-942. https://doi.org/10.1111/tmi.12331

[3] Tilley, E., Strande, L., Lüthi, C., Mosler, H.-J., Udert, K.M., Gebauer, H. and Hering, J.G. (2014) Looking beyond Technology: An Integrated Approach to Water, Sanitation and Hygiene in Low Income Countries. Environmental Science \& Technology, 48, 9965-9970. https://doi.org/10.1021/es501645d

[4] OMS (2011) Directives de qualité pour l'eau de boisson. Quatrième édition. Publication Organisation Mondiale de la Santé, Genève, 307-447.

[5] Brian, O. (2007) Environmental Quality Centre Environmental Engineering and Earth Sciences Wilkes University. Wilkes-Barre, PA 1876.

[6] O'Brien, R.E. (2010) Water Resources in Sub-Saharan Africa: The Case of Mali. University in St. Louis, Washington DC.

[7] Baig, R., Xu, S.A. and Khan, X. (2012) Microbial Water Quality Risks to Public Health: Potable Water Assessment for a Flood-Affected Town in Northern Pakistan. Rural and Remote Health, 12, 2196.

[8] E.T.D.E.S. Finances, B. (2009) Central, D.U. Recensement, 4 ème Recensement General de la Population et de l'Habitat du Mali (RGPH-2009) Analyse des résultats définitifs Theme 2 .

[9] AFD (2016) Diagnostic Territorial de la Region de Segou au Mali. 150 p.

[10] Toure, A., Duan, W., Keita, Z. and Dembele, A. (2018) Investigation of the Water Quality of Daily Used Surface-Sources for Drinking and Irrigation by the Population of Segou in the Center of Mali. Journal of Water and Health, 17, 338-349. https://doi.org/10.2166/wh.2018.085

[11] APHA, American Public Health Association (1998) Standard Methods for Examination of Water and Wastewater. 20th Edition, American Public Health Association, Washington DC.

[12] Stevens, M., et al. (2003) Review of Coliforms as Microbial Indicators of Drinking Water Quality Recommendations to Change the Use of Coliforms as Microbial Indicators of Drinking Water Quality. Aust. NHMRC, Biotext Pty Ltd., Canberra, $1-42$.

[13] Akoachere, N., et al. (2008) Bacterial Indicators of Pollution of the Douala Lagoon Cameroon: Public Health Implication. African Health Sciences, 8, 85-89.

[14] Abdelrahman, Y.M. and Eltahir, A.A. (2010) Bacteriological Quality of Drinking Water in Nyala, South Darfur, Sudan. Environmental Monitoring and Assessment, 175, 37-43. https://doi.org/10.1007/s10661-010-1491-7 
[15] Belghiti, M.L., Chahlaoui, A. and Bengoumi, D. (2013) Étude de la qualité physico-chimique et bactériologique des eaux souterraines de la nappe plio-quaternaire dans la région de Meknès (Maroc). Larrhyss Journal, 14, 21-36.

[16] Gnagne, T., Touré, Y.G., et al. (2008) Concertation des acteurs pour un accès durable des populations à faibles revenus au réseau public d'eau potable: Cas de Koweit dans la commune de Yopougon. Revue de Géographie tropicale et dEnvironnement (Geotrope). 2, 63-75.

[17] Soncy, K., Djeri, B., Anani, K., Eklou-Lawson, M., Adjrah, Y., Karou, D.S., Ameyapoh, Y. and De Souza, C. (2015) Évaluation de la qualité bactériologique des eaux de puits et de forage à Lomé, Togo. Journal of Applied Biosciences, 91, 8464-8469. https://doi.org/10.4314/jab.v91i1.6

[18] William, L. (2014) Assessment of Borehole Water Quality and Consumption in Yei.

[19] Toure, A., Wenbiao, D. and Keita, Z. (2018) An Investigation of Some Water Quality Properties from Different Sources in Pelengana Commune, Segou, Mali. Journal of Water, Sanitation and Hygiene for Development, 8, 449-458. https://doi.org/10.2166/washdev.2018.172

[20] El Haissoufi, H., Berrada, S., Merzouki, M., Aabouch, M., Bennani, L., Benlemlih, M., Idrir, M., Zanibou, A. and Bennis, Y. (2011) Pollution Des Eaux De Puits De Certains quartiers de la ville de Fes, Maroc. Revue de Microbiologie Industrielle, Sanitaire, et Environnementale, 5, 37-68.

[21] Knappett, P.S.K., McKay, L.D., Layton, A., Williams, D.E., Alam, M.J., Mailloux, B.J., Ferguson, A.S., Culligan, P.J., Serre, M.L., Emch, M., et al. (2012) Unsealed Tubewells Lead to Increased Fecal Contamination of Drinking Water. Journal of Water and Health, 10, 565-578. https://doi.org/10.2166/wh.2012.102

[22] Kumpel, E. and Nelson, K.L. (2013) Comparing Microbial Water Quality in an Intermittent and Continuous Piped Water Supply. Water Research, 47, 5176-5188. https://doi.org/10.1016/j.watres.2013.05.058

[23] WHO (2004) Guidelines for Drinking Water Quality. Geneva, Vol. 1, 3r.

[24] Ologe, J.O. (1989) Household Water in Rural Kwara. Water Engineering and Development in Africa: Proceedings of the 15th WEDC Conference, Kano, Nigeria, Loughborough University of Technology, 3-7 April 1989, 169 p.

[25] Laukova, P. and Juris, A. (1997) Distribution and Characterization of Enterococcus Species in Municipal Sewage. Microbiology, 89, 73-81.

[26] Rodier, N., Legube, J. and Merlet, B. (2009) Analyse de l'eau. 9th Edition, DUNOD, Paris, 1579 p.

[27] Momba, T.L. and Notshe, M.N.B. (2003) The Microbiological Quality of Ground Water after Long Storage in House Hold Container in a Rural Community of South Africa. Journal of Water Supply: Research and Technology-Aqua, 52, 67-77. https://doi.org/10.2166/aqua.2003.0007

[28] Onwughara, N.I., Ajiwe, V.E., Nnabuenyi, H.O. and Chima, C.H. (2013) Bacteriological Assessment of Selected Borehole Water Samples in Umuahia North Local Government Area, Abia State, Nigeria. Journal of Environmental Treatment Techniques, 1, 117-121.

[29] Turnbull, P.C.B. (1996) Medical Microbiology. 4th Edition, The University of Texas Medical Branch, Galveston.

[30] Kistemann, F., Classen, T., Koch, T., et al. (2002) Microbial Load of Drinking Water Reservoir Tributaries during Extreme Rainfall and Runoff. Applied and Environmental Microbiology, 65, 251-264. 